\title{
ROMAN DOMESTIC ART AND EARLY CHRISTIAN TRADITIONS
}

\section{Book Title:}

Roman Domestic Art and

Early House Churches

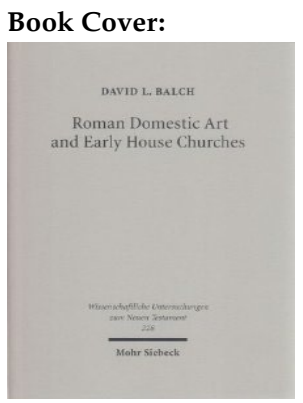

Author:

David L. Balch

ISBN:

978-3-16-149383-6

Publisher:

Mohr Siebeck, Tübingen, 2008 , pp. 296 plus CD, €99.00* *Book price at time of Review

Review Title:

Roman domestic art and early Christian traditions

\section{Reviewer:}

Jan W. van Henten ${ }^{1}$

\section{Affiliation: \\ ${ }^{1}$ School for Humanities, University of Amsterdam, The Netherlands \\ email: \\ j.w.vanhenten@uva.nl}

Postal address:

School for Humanities, University of Amsterdam, 210 Spui Street 210 1012VT Amsterdam, The Netherlands

How to cite this book review: Van Henten, J.W., 2010, 'Roman domestic art and early Christian traditions', HTS Teologiese Studies/ Theological Studies 66(1), Art. \#999, 1 page. DOI: 10.4102/hts.v66i1.999

This review is available at: http://www.hts.org.za

(c) 2010. The Authors. Licensee: OpenJournals Publishing. This work is licensed under the Creative Commons Attribution License.
David Balch is well-known for his research into early Christian house churches and families. This innovative book is a collection of revised essays, which have been published separately elsewhere. It focuses on the interconnections between Roman domestic art and early Christian traditions. The main evidence comprises the frescoes and mosaics found in Italian domus (houses) and insulae (apartment buildings), including the rich findings at the cities of Pompeii and Herculaneum, which were destroyed by the grand eruption of the Vesuvius in 79 AD.

The introduction deals with the set up of Roman houses and the categorizations of Roman domestic art in secondary literature. Chapter 1 focuses upon shops and rich houses in Pompeii and the large multistory buildings (insulae) in Herculaneum in connection with the spaces where Pauline house churches may have met. The large atria and dining rooms in these houses imply that Pauline house churches were not necessarily small. Chapter 2 deals with the 'Egyptomania' in Roman domestic art. Balch connects depictions of the suffering goddess Isis, who was associated with Io in Graeco-Roman religion, with Jesus' crucifixion. He claims that the tragic art in Italian houses emphasising pathos functioned as a meaningful cultural context for those who heard Paul proclaiming the Gospel (p. 61). Chapter 3 connects Paul's portrait of Christ crucified in Galatians 3:1 with art works about suffering and death in Pompeian and Roman houses, depicting Iphigeneia, the Laocoon group and the dying Gauls. Chapter 4 deals with myths represented in Nero's Golden House and two dining rooms in the House of the Vettii in Pompeii, which are associated with Mark 13:12-13 and 1 Clement 6.2. Balch argues that these representations illuminate the cultural context in which early Christians re-interpreted Roman values in connection with situations of persecution. Chapter 5 focuses on the woman clothed with the sun pursued by the dragon $(\mathrm{Rv} 12)$ in connection with representations of the pregnant Io in the Isis Temple at Pompeii. John subverted the imperial visual representation of a pregnant goddess whose giving birth generated a cosmic battle. Chapter 6 compares the popular figure of Endymion, depicted in the domus as well in the catacombs, with Jonah, the most popular figure in Christian catacombs prior to Constantine. Chapter 7 offers a survey of the representations in 194 Pompeian dining rooms and also deals with the visualisation of aspects of Roman imperial ideology in these rooms. The book also includes a glossary and several indices, as well as a CD with 307 plates (of which a selection is incorporated in the book).

The book offers a wealth of material about Roman domestic art from which scholars of early Christian literature can benefit tremendously. A tabulinum in the Casa del Granduco, for example, includes the scene of Dirce's punishment. She was dragged to death by a bull in the amphitheater (pp. 27-28, 130138). This dramatic scene, depicted at least eight times in domestic art, helps to understand why Clement of Rome mentions it by way of comparison in his reference to the martyrdom of female Christians (1 Clem. 6.1-2). The detailed discussion of representations of Isis and Io contributes considerably to the interpretation of Revelation 12. The book raises questions as well. How should we assess the interconnections between early Christian textual material and the visual evidence discussed in this book? Sometimes Balch may underestimate the complexities of these interconnections. Representations of Io just may enlighten Paul's references of the crucifixion, but it is important to note that Paul's references lack a visual description. Balch uses the word 'portrait' in connection with Galatians 3:1, but Paul does not depict the crucifixion scene in this passage. The earliest visual depiction of Jesus on the cross is much later than the early imperial domestic art discussed, as Balch acknowledges. Balch also argues that domestic art helps to bridge the gap of 450 years between Euripides' tragedies and Paul's passages about the beneficial effect of Jesus' death. Iphigeneia's sacrifice is represented by several Pompeian frescoes (p. 39), but Euripides' tragedies also remained well-known because they were copied many times, as papyrological evidence shows. Balch focuses upon the correspondences between Italian domestic art and early Christian traditions and practices, but what about the differences? Many scenes depicted in domestic art are extremely violent, including representations of defeated enemies. Women are often depicted half naked. The House of the Vettii includes an ithyphallic Priapus (a manifestation of Dionysus) with an enormous penis at the doorway. The Casa dei Vettii depicts males and females engaged in sexual activities. Should we not assess such scenes as well if we want the full picture? Nevertheless, we should be extremely grateful for Balch surveying this rich and important source of evidence for contextualising early Christianity in a fascinating and very competent way. 